\title{
MARIOLA SOBOLEWSKA \\ THE JOHN PAUL II CATHOLIC UNIVERSITY OF LUBLIN
}

\section{THE PERCEPTION OF ORPHICS FROM I BC TO III AD}

SUMMARY: In my article I examined rare mentions about Orphics in texts of Christian (i.e. Athenagoras, Origen, Clement of Alexandria, Eusebius of Ceasarea, Theophilus of Antioch, Pseudo-Justin) and non-Christian authors (i.e. Diodorus of Sicily, Strabo, Plutarchus). I established that Christian authors as well as non-Christian authors in I BC - III AD had the worst possible opinion about Orphics and their practices.

KEYWORDS: Orphics, Orphic beliefs, Christian authors, non-Christian authors

It would have been difficult in the period from I BC to III AD to find a moderately cultivated person who had never heard of the Orphic rites. First, there is no proof of the existence of any religious group known as the "Orphics" in the Classical period. The continuity between early and late Orphism is guaranteed as much, if not more, by the evidence of external observers, even the detractors, as it is by the imagined successive handing down of tradition across generations of "Orphics". In my article I will try to discuss emotionally charged mentions of Christian and non-Christian authors about Orphism in I BC - III AD ${ }^{1}$.

My article refers to the period from 146 years BC to IV AD (i.e. Neoplatonists). About Orphism and Neoplatonists see: Brisson 1995: 43-103; 157-209; Brisson 2008: 1491-1517; Edmonds 2013: 37-43. About Orphism in the Roman Empire period see: Boulanger 1937: 121-135; Brisson 1990: 2867-2931; Herrero 2008: 1383-1411; Santamaría 2008: 1411-1442; Edmonds 2013: 24-27. 


\section{CHRISTIAN AUTHORS}

Christian texts are fundamental for the understanding of not only the Orphism of the Imperial age, but also that of the Classical period, on three levels. First, much of the material that we have for the reconstruction of Orphism - very considerable in its quantity, and of great importance for its quality - comes from Christian sources: it is enough to look at the index fontium of the editions of Orphica.

However, this material must not be used without a prior analysis of the sources, intentions, and manipulations of the author who transmits it, since the apologetic literature is anything other than innocent and neutral, because Christianity competed with Orphism².

Such is the context within which several Christian authors of the first $\mathrm{BC}$ to fourth centuries $\mathrm{AD}$ make their multiple references to Orphism. Firstly we will observe how their beliefs and practices were perceived by Christian authors.

2 Orphism is a forerunner of Christianity in the Greek world - an idea that, as we shall see, had already been formulated by some ancient writers, and that took root again strongly when nineteenth-century philology focused on Orphism as a subject of study. It is only a small step, and one very easy to take, from postulating spiritual precedence to supposing historical dependence. Here the study of Orphism is framed within a broader intellectual fashion, the comparison of Christianity with ancient mystery cults. The debate was long, complex and brilliant, and outstanding figures like the German scholars Albrecht Dieterich (Dieterich 1913), Richard Reitzenstein (Reizenstein 1927), Wilhelm Bousset (Bossuet 1913), the British anthropologist Sir James Frazer (Frazer 1913), or the Belgian Franz Cumont (Cumont 1929), on the one hand, and Carl Clemen (Clemen 1913) or Arthur Darby Nock (Nock 1928), on the other, left many contributions which retain a great significance today. While the comparatists showed the manifold coincidences between Christian texts, rites and ideas and those of the mystery cults, the other side developed various methodological lines which sought to underline the differences. About the associations of Orphism with Christianity see: Irwin 1982: 51-62; Vicari 1982: 63-83; Casadio 1990: 185-204; Herrero 2008B: 15271574; Herrero 2010; Jourdan 2010A; Jourdan 2010B; Jourdan 2011; Edmonds 2013: 31-37; Jourdan 2015: 193-206. 


\section{ATHENAGORAS}

He presses charges against the Greek poets and philosophers because they claim that the gods are of material origin, and therefore cannot live forever, and furthermore commit acts unworthy of divine beings $^{3}$. He draws many examples for his case from the Orphic Theogony. It should be highlighted, however, that almost all his statements about Orphics are negatively biased. Athenagoras introduces an entire section of the Legatio on the Greek gods by saying that Orpheus, Homer, and Hesiod were those who established the genealogies and names of the gods ${ }^{4}$. Of the three, it is the most ancient, Orpheus, whom he will place at the center of his exposition.

He said that the theogony of the Orphics is absurd, because, according to them, the gods came to life from water ${ }^{5}$. Athenagoras makes use of the Stoic source in order to criticize the materiality of gods who, having originated in water and earth, cannot be eternal: "The gods do not

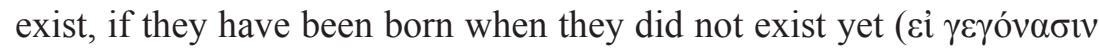

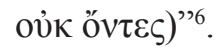

He also thought that their belief is unworthy of respect ${ }^{7}$, and their gods have animal form and ugly appearance ${ }^{8}$. This Christian apologist accused Orphics also that they invented various pieces of false information about Christianity and presented them as they presented their own beliefs, that is in unworthy way ${ }^{9}$. Athenagoras was also disgusted by descriptions of sexual intercourse between different deities which were featured prominently in Orphic mythology. He spoke negatively about uninhibited sexual freedom postulated by the worshipers of Orpheus through their mythology ${ }^{10}$. We notice then that this Christian author had, because of his faith, the worst possible opinion about Or-

About Orphism at Athenagoras see: Ferwerda 1973: 104-115.

Athenag. Pro Christ. 17, 1.

Athenag. Pro Christ. 20, 1.

West 1984: 53-56. About associations Orphism with Stoicism see: Casadesús 2008B: 1307-1337.

Athenag. Pro Christ. 20, 4.

Athenag. Pro Christ. 20, 4.

Athenag. Pro Christ. 32, 1.

Athenag. Pro Christ. 32, 1. 
phic beliefs, and, what is interesting, he expressed it relatively often. Consequently, we can come to the conclusion that Orphics had to bother him immensely, if at any cost he tried to discredit them in the eyes of readers of his work.

\section{ORIGEN}

A slightly different attitude towards the Orphic conceptions were represented by Origen. He said that the beliefs and Orpheus' teachings are nothing more than invented fables ${ }^{11}$. In another passage of his work he calls the beliefs from the verses of the Thracian songster unholy ${ }^{12}$. The purpose of these statements was to convince the readers that the Orphic beliefs are only an unholy figment that has nothing to do with reality. The Christian apologist spoke with disapproval also about the Orphic mysteries, during which, according to him, priests induced "phantoms and objects of terror" ( gen wrote that:

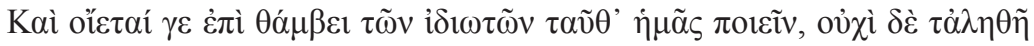

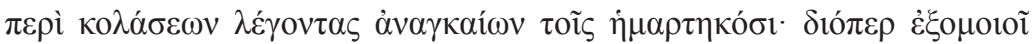

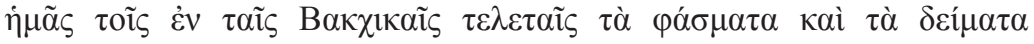

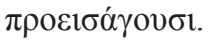

He imagines that we do these things to excite the astonishment of the ignorant, and that we do not speak the truth regarding the necessity of punishments for those who have sinned. And accordingly he likens us to those who in the Bacchic mysteries introduce phantoms and objects of terror (trans. F. Crombie) ${ }^{14}$.

This description did not have a positive influence on the perception of religious practices of Orphics at that time.

It is, however, possible that the work of Origen was not aimed at discrediting the teachings of Orpheus, but to denigrate the message of

11 Origen. c. Cels. 1, 17.

12 Origen. c. Cels. 7, 54.

13 Origen. c. Cels. 4, 10.

14 Origen. c. Cels. 4, 10. 
Celsus. Certain information that we find in this Christian author suggest that he, perhaps not consciously, allowed for equality of the belief of Orphics and Christians. He has written that:

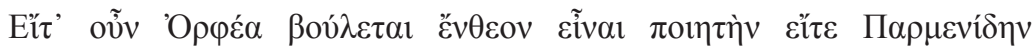

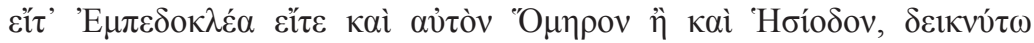

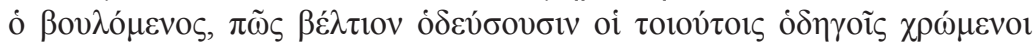

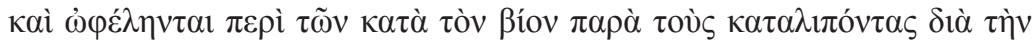

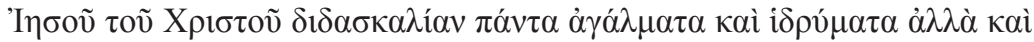

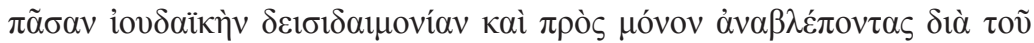

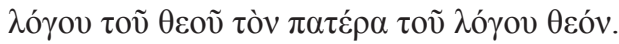

But whether Orpheus, Parmenides, Empedocles, or even Homer himself, and Hesiod, are the persons whom he means by inspired poets, let any one show how those who follow their guidance walk in a better way, or lead a more excellent life, than those who, being taught in the school of Jesus Christ, have rejected all images and statues, and even all Jewish superstition, that they may look upward through the Word of God to the one God, who is the Father of the Word (trans. F. Crombie) ${ }^{15}$.

In another passage Origen's response to Celsus, who had said that Orpheus, Linus, and Musaeus "had written their dogmas in books", challenges his opponent: "Compare books with books ( $\beta i \beta \lambda$ ovs $\beta i \beta \lambda o r \varsigma$ $\pi \alpha \rho \alpha \beta \alpha \dot{\lambda} \lambda \varepsilon \sigma \theta \alpha 1)$; contrast the poems of Linus, Musaeus, Orpheus, and the prose of Pherecydes with the laws of Moses, comparing histories with histories, ethical discourses with laws and commandments"16. Origen attributes to the legendary figures of Greek religion books comparable to the Bible and doctrines in the style of Christian dogmas. Here, we can see clearly that the Christian apologist personally did not have such a negative an attidude towards the beliefs of Orphics. The question why he did not attack Orphics as much as it appeared necessary, remains open. It is possible that he sensed some analogies and similarities between Orphics, represented by his adversary - Celsus, who spoke favorably about the teaching of the Thracian songster and Christians. Therefore this Christian author's critique should be looked at from a specific point of view.

\footnotetext{
15 Origen. c. Cels. 7, 41.

16 Origen. c. Cels. 1, 16-18.
} 
Radcliffe G. Edmonds undoubtedly rightly draws the attention to the fact that many later apologists used Orpheus' name for the similar purpose as Origen. It was a pretext for attacking all of Greek tradition, which associated many phenomena with the person of the Thracian songster ${ }^{17}$. This is the reason that Orpheus ends up as the apologists' preferred enemy: he is a figure of recognized prestige, but at the same time highly vulnerable to attack because he is the one who presents the most scandalous myths. Therefore Orphics as the disciples of Orpheus are not the target of the attack themselves.

\section{CLEMENT OF ALEXANDRIA}

Clement of Alexandria (mid-second century to early third) is the author most crucial to this study, for he attributes the greatest significance to the Orphic tradition both as a representative of Greek religion and as a pagan forerunner of Christian truths. His three main works are the Protrepticus ${ }^{18}$, or Exhortation to the Heathen, inviting the pagans to convert to Christianity; the Paedagogue, outlining a norm of ethical behavior for the good Christian; and the more extended and varied work entitled Stromata, depicting the spiritual life of the "true Gnostic". In any event, Clement's most important Orphic references are found in the

\footnotetext{
17 Edmonds 2013: 34.
}

18 In the Protrepticus Clement adapts a traditional philosophical genre following all the rhetorical conventions of a suasory discourse. It is built upon the basic and wellestablished structure exordium - refutatio - argumentatio - peroratio, and within each section Orphic elements play a fundamental role. In the exordium, Orpheus's old song is juxtaposed against the new song of Christ (Book 1), who is thus presented as a new Orpheus, bringing true religion instead of false superstition; the refutatio opens with sharp criticism of Orphic mysteries (2, 12-22); at the end of the argumentatio Clement proves by means of the Testament the conversion of Orpheus himself (7, 74, 3-6); and in the peroratio he casts light upon the proclamation of the mysteries of Christ using Bacchic and Eleusinian terminology $(12,119-122)$. About Orphism at Clement of Alexandria see: Marcovich 1973: 359-360; Jourdan 2006: 265-282; Herrero 2007: 1950; Bernabé 2008: 79-99; Jourdan 2008: 319-333; Pérez 2010: 119-132; Pérez 2011: 113-131. 
Protrepticus and the Stromata. Clement of Alexandria informs us that Orphic mysteries are "shameless"

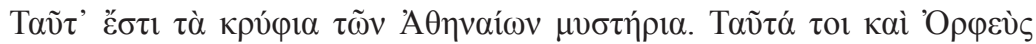

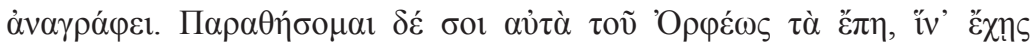

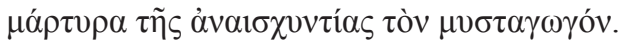

These are the secret mysteries of the Athenians; these Orpheus records. I shall produce the very words of Orpheus, that you may have the great authority on the mysteries himself, as evidence for this piece of shamelessness (trans. W. Wilson) ${ }^{20}$.

On this basis we can easily guess that Christian authors attacked Orphics and the beliefs they professed to persuade them into their own. However, their critique was limited only to certain unfavourable epithets directed to them and highlighting from the point of view of their practiced morality of particular "shamelessness" of relationships between the gods worshiped by Orphics.

\section{EUSEBIUS OF CEASAREA}

Eusebius does not have direct knowledge of Orphic tradition. But he is the only Christian author that appeared to have a more positive attitude towards Orphics was Eusebius of Ceasarea, who even referred to the teachings of Orpheus to some extent as beneficial for people ${ }^{21} \mathrm{He}$ wrote about them as follows:

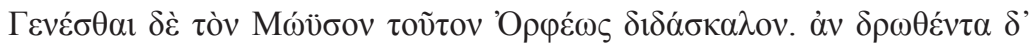
$\alpha$

And this Moses, they said, was the teacher of Orpheus; and when grown up he taught mankind many useful things (trans. E.H. Gifford).

It should be that this opinion of the man from Caesarea is in this matter very much isolated and, unfortunately, it cannot be determined what exactly was meant by beneficial.

\footnotetext{
19 Clem. Protr. 2, 21, 1.

20 Clem. Protr. 2, 21, 1.

21 Euseb. Praep. Ev. 9, 27, 3.
} 
In another place in the work of Eusebius we can read, however, that the beliefs and teachings of Orpheus, Musaeus and Linus are "incorrect"22. Therefore, we can see that the author of the Church history had mutually exclusive opinions about the teachings of Orpheus, which opinions depended mostly on what he needed at the moment.

Fabienne Jourdan presented many useful remarks on Eusebius of Caesarea's perception of Orphics. She has determined that the major source for this man from Caesarea in the subject of the Orpheus' teachings and their provenience had been the work of Diodorus of Sicily ${ }^{23}$. On the basis of this, we can see that Eusebius drew information about Orphics from an indirect source, moreover, of a non-Christian provenience. This may be the reason why the opinions he expressed about the followers of Orpheus' teachings are mutually exclusive.

\section{OTHER CHRISTIAN AUTHORS}

The other Christian authors in the period in which we are interested also did not have a positive opinion about the teachings promoted by Orphics. Theophilus, a bishop of Antioch, left a single work - an Apologia to Autolycus in three books. Its main topic is the inferiority of Greek culture with regard to Biblical revelation. Theophilus denies that Orpheus discovered music, and quotes his Testament. Theophlius of Antioch thought that the message of Orpheus is "empty and void"

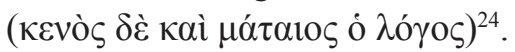

Pseudo-Justin is the first of the apologists to allude to the Orphic tradition. In this pseudoepigraphic corpus (conventionally known as Pseudo-Justin), two works contain important Orphic quotations. De monarchia is a brief work, probably written by a Jewish author between the first century $\mathrm{BC}$ and the first century $\mathrm{AD}$, that accumulates

\footnotetext{
22 Euseb. Praep. Ev. 10, 4, 4.

23 Jourdan 2010: 175, n. 716.

24 Theophil. ad Autolyc. 2, 30. Dio Chrysostom (non-Christian author) spoke in a similar way about this matter, claiming that the stories of the Thracian songster are

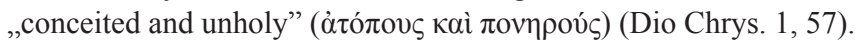


Greek literary quotations, among them the so-called Testament of Orpheus, in order to prove the existence of monotheism in Greek culture.

According to Pseudo-Justin, in turn, the teachings of the master of Orphics are "faulty" and he even regrets it is $\mathrm{so}^{25}$.

\section{NON-CHRISTIAN AUTHORS}

Let us take a look at this point at how Orphics and their beliefs were perceived by other ancient writers who were not Christians.

\section{DIODORUS OF SICILY}

In the first century BC Diodorus acted as a catalyst for the earlier tradition about the Orphic rites and gave it new force, as Alberto Bernabé has shown in two studies of his Orphic references ${ }^{26}$. The Sicilian historian collected various traditions related to Orpheus and his rites, many of them derived from earlier authors, especially Hecataeus and Dionysios Scytobrachion. Diodorus usually refers to the foundation of rites by Orpheus, "the greatest of the Greeks in accounts of the gods (theologiai) and teletai" 27.

Diodorus of Sicily presented a slightly different attitude towards the Orphics concepts. He thought that the stories from ancient mythographers and poets and probably Orpheus about Dionysus are "monstrous"28. It appears that even for the Greek author who believes in traditional, Homeric-Hesiodic mythology, Orphic concepts caused fear, similar to the one felt towards them by Origen, who was raised Christian.

We can find out from Diodorus that Orpheus was respected by Greeks because of his initiations and the knowledge of gods that he

\footnotetext{
25 Ps-Iustin. De monarch. 2, 4.

26 About Orphism at Diodorus see: Bernabé 2000: 37-53; Bernabé 2002A : 67-96.

27 Diod. 4, 25, 3; 1, 23, 6.

28 Diod. 3, 62, 2.
} 
passed to them ${ }^{29}$. Unfortunately, we cannot assume on this basis that Orphics were treated everywhere in a similar way at least in the times of Orpheus, although, in some regions of Greece the esteem for Orpheus could cause respect for their followers.

\section{STRABO}

Strabo seems to call Orphica precisely those Greek rites that are similar to the foreign ones, like those of Bendis and Cotys in Thrace and Phrygia ${ }^{30}$. Strabo says that the Orphica originated in the rites of Bendis in Phrygia. The foreign origin of the Orphic rites is a possible explanation of their exceptional position in the panorama of Greek religion, but it seems that this unusual status should rather be ascribed to the experience of "otherness" that the cult of Dionysus could produce in his followers.

Strabo had an even different way of speaking about the followers, or rather immediate disciples, of Orpheus. He called them a mob (ó $\chi \lambda \mathrm{s} \varsigma$ ). Some of them were supposed to follow willingly, other suspicious ones were scheming against him or acted "violently" and by this brought his "downfall" 31 . This information appears, however, to refer to the mythical times and does not describe the disciples of Orpheus from the times of Strabo, which does not have to mean that he did not perceive them in that way.

In the same fragment of Strabo's work, which was pointed out by Raquel M. Hernández, there is one more negative statement about Orphics. Strabo thought that Orpheus was just a vendor of initiation rites to Greeks ${ }^{32}$. The Spanish scholar, undoubtedly rightly, highlights the fact that Strabo's negative perception of Orphic priests was not a result of observation but rather of the suggestion that we find about them in Plato in the fragment I mentioned several times ${ }^{33}$.

\footnotetext{
29 Diod. 1, 23, 2; Philostr. Heroic. 28, 11.

30 About Orphism in Strabo see: Bernabé 2002B: 59-66.

31 Strab. 7 fr. 10 a Radt.

32 Strab. 7 fr. 10 a Radt.

33 Plat. Resp. 363 e-365 a. Hernández 2006: 114.
} 


\section{PLUTARCHUS}

Two centuries after Diodorus and Strabo, and much more original and critical in his treatment of sources, Plutarchus also makes frequent mention of Orphic rites ${ }^{34}$. Not all Plutarchus references come from literary sources, in contrast to Diodorus's case; rather, a celebrated passage demonstrates that he knew the mysteries of Dionysus from direct experience: "And what you have heard from others, who seek to persuade many, saying that for the one who has died there does not exist any evil or pain anywhere - I know that you are prevented from believing it by the teaching of our fathers and the mystical tokens of the celebra-

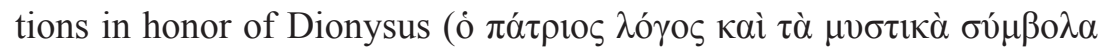

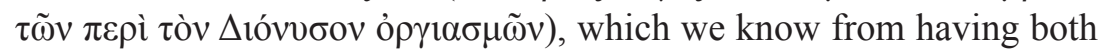
participated in them. Well, then, consider that the soul, being immortal, undergoes the same things as birds in captivity" ${ }^{35}$. Plutarchus, who devoted great deal of space to describe the teachings of Orphics, did not fully understand their conceptions and practiced rituals. One can receive an impression that to the Chearonean they appeared at least peculiar, which is suggested by the tone of his statement ${ }^{36}$. It is possible that it happened because he knew Orphic conceptions only in a secondhand manner, what he appears to inform us about by quoting a famous passage from Plato in which the philosopher ridiculed the followers of Orpheus for their belief in everlasting drinking that awaits them after death $^{37}$. On the basis of this we can infer that the Cheronaean knew the convictions of Orphics mostly only from works of other authors, for example of Plato. His lack of understanding of Orphic beliefs made him, as well as Christian apologists, express his belief in the absurdity of their claims, in defence of which he put forward some arguments.

An example of this kind of practice is the story about an orpheotelest who was teaching about eternal happiness awaiting after death,

\footnotetext{
34 About Orphism in Plutarchus see: Bernabé 1996: 63-104; Bernabé 2001: 5-22; Jourdan 2005: 153-174; Aguilar 2011: 237-241.

35 Plut. Cons. ad Uxor. 10. A. Bernabé links this passage with the bird mentioned in the first columns of the Orphic Derveni Papyrus, which in his reading would be liberated from a cage (Bernabé 2007B: 157-170).

36 Plut. De E ap. Delph. 9, 389.

37 Plat. Resp. 363 c; Plut. Compos. Cimon. et Luc. 1, 2.
} 
who however did not want to commit suicide to support his beliefs ${ }^{38}$. Plutarchus has written that:

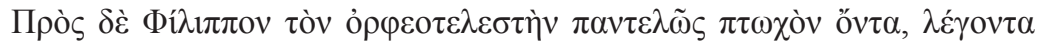

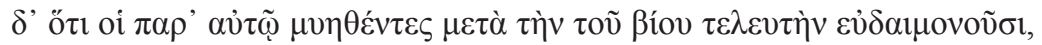

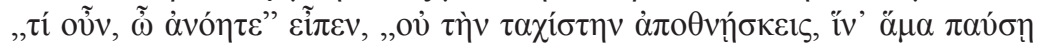

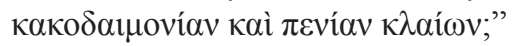

This is his retort to Philip, the priest of the Orphic mysteries, who was in the direst straits of poverty, but used to assert that those who were initiated under his rites were happy after the conclusion of this life; to him Leotychidas said, ,You idiot! Why then don't you die as speedily as possible so that you may with that cease from bewailing your unhappiness and poverty?" (trans. F.C. Babbitt) ${ }^{39}$.

Likewise, his mention of the orpheotelestes before Leotychides, the Spartan $\mathrm{king}^{40}$, is in the same burlesque tradition as those of Theophrastus and Philodemus, reflecting a stock comic personage more than actual acquaintance (OF 653-655). But Plutarchus by putting forward this anecdote clearly mocks Orphic beliefs and their teachers, additionally highlighting the fact that they only try to earn money using their message. Francesc Casadesús, however, rightly draws the attention to the fact that this story comes from the fifth century BC, not from the times of Plutarchus, and that it cannot be related to the period of interest to us ${ }^{41}$. R.M. Hernández, analysing the above fragment draws the attention to the fact that the orpheotelest described by Plutarchus lived in extreme poverty and this makes it his most important feature that was supposed to characterise the followers of Orpheus, not the discrepancy of their beliefs ${ }^{42}$.

A. Bernabé in his works writes a great deal about Plutarchus' perception of Orphic beliefs.

He thought that the Chaeronean perceives Orpheus as a theologian or even a philosopher wondering about essential truths. However,

\footnotetext{
38 Plut. Apophth. Lacon. 224 d.

39 Plut. Apophth. Lacon. 224 d..

40 Plut. Apophth. Lacon. 224 d.

41 Casadesús 2008A: 478.

42 Hernández 2006: 569-570.
} 
according to the Spanish scholar, Plutarchus speaks about the Thracian songster's "philosophy" in an enigmatic way, and he adds that the mysteries of the Orphic theology were shown in rites in a symbolic way ${ }^{43}$. A. Bernabé views on these matters appear undoubtedly right, which only confirms my hypothesis that Plutarchus did not entirely understand Orphic concepts.

The only evidence that can indicate that Plutarchus could, at least to a small extent, know the mores of Orphics first hand is his remark about their piety. In the work about oracles, the Cheronean highlights the fact that, because of the teachings of Orpheus for Greeks, the rites connected to death and mourning are celebrated in the ardent manner ${ }^{44}$. He has written that:

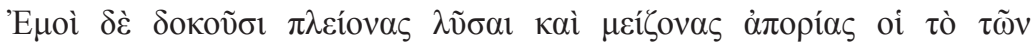

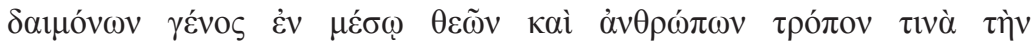

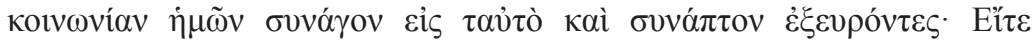

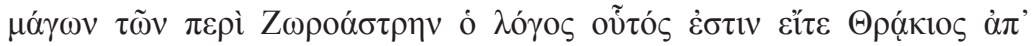

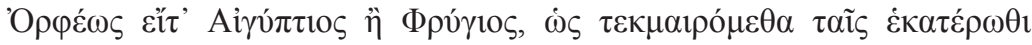

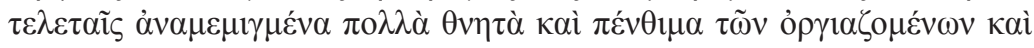
$\delta \rho \omega \mu \varepsilon ́ v \omega v$ i $\varepsilon \rho \tilde{o} v$ ó $\tilde{v} v \tau \varepsilon \varsigma$.

But, as it seems to me, those persons have resolved more and greater perplexities who have set the race of demigods midway between gods and men, and have discovered a force to draw together, in a way, and to unite our common fellowship — whether this doctrine comes from the wise men of the cult of Zoroaster, or whether it is Thracian and harks back to Orpheus, or is Egyptian, or Phrygian, as we may infer from observing that many things connected with death and mourning in the rites of both lands are combined in the ceremonies so fervently celebrated there (trans. F.C. Babbitt $)^{45}$.

In addition, it is one of the rare positive remarks about them in works of non-Christian authors. Orphics' emotional commitment in performing rituals had to make them stand out against the followers of the traditional Greek religion.

\footnotetext{
43 Bernabé 2007A: 59.

44 Plut. De def. orac. 10, 415 a.

45 Plut. De def. orac. 10, 415 a.
} 
On the basis of the fragments presented above, it is easy to notice that the source Plutarchus used showed a very negative image of Orphics. They might have been texts from earlier times, but there also might have been among them those written during his lifetime.

\section{CONCLUSIONS}

On the basis of our findings so far, we can come to the conclusion that the Christian authors as well as non-Christian authors in I BC - III AD had generally the worst possible opinion about Orphics and their practices. The criticisms levied by Athenagoras, Origen, Clement, Theophilus, Pseudo-Iustin, Eusebius, Plutarchus, Diodorus, and Strabo at the myths, rituals, and symbola of the Greek mysteries are focused on rites and ignore or deride of any possible doctrinal contents. Positive remarks about Orphics are extremely rare. The Christians were in agreement, then, with the philosophical tradition in evaluating certain aspects of Orphism positively. However, the continuity is even greater in the sphere of criticism. The attack on the myths as inappropriate representations of the image of the truly divine is a constant of the Greek philosophical tradition going back to Xenophanes in the sixth century B.C. The mythological gods' subjection to human passions is incompatible with the venerable impassivity that philosophy presumed of the divine. The attacks on Orpheus by Athenagoras, Origen, Clement, Theophilus, Dion, Pseudo-Justin, Eusebius, Plutarchus, Diodorus, and Strabo are direct heirs of the Presocratic and Platonic criticism of myth, and their intellectual authority comes from their continuity with so prestigious a tradition. However, it should be noted that the remarks presented by me in this part, coming from the works of different authors are almost all of the references that expressed in this period any kind of an emotional attitude of external observers towards Orphics. 


\section{BIBLIOGRAPHY}

\section{Primary sources}

Ante-Nicene Fathers, 1885, eds. A. Roberts, J. Donaldson, A. Cleveland Coxe, vol. 2, Buffalo.

Ante-Nicene Fathers, 1885, eds. A. Roberts, J. Donaldson, A. Cleveland Coxe, vol. 4, Buffalo.

Plutarch, 1931, Moralia, ed. J. Henderson, vol. 3, Cambridge.

Plutarch, 1936, Moralia, ed. J. Henderson, vol. 5, Cambridge.

\section{Secondary sources}

Aguilar R. M., 2011, 'Reflejos del orfismo en Plutarco (OF 524, 358 II, 31 V; Epimen. fr. 43)', [in:] M. Herrero, A. I. Jiménez, M. A. Santamaría (eds.), Tracing Orpheus. Studies of Orphic Fragments in Honour of Alberto Bernabé, Berlin, pp. 237-241.

Bernabé A., 1996, 'Plutarco e l'orfismo', [in:] I. Gallo (ed.), Plutarco e la religione. Atti del VI Convegno plutarcheo (Ravello, 29-31 maggio 1995), Napoli, pp. 63-104.

Bernabé A., 2000, 'Tradiciones órficas en Diodoro', [in:] M. Anganza (ed.), EПIEIKEIA. Studia Graeca in Memoriam J. L. Tuero, Granada, pp. 37-53.

Bernabé A., 2001, 'La experiencia iniciática en Plutarco', [in:], A. Pérez Jiménez, F. Casadesús (eds.), Estudios sobre Plutarco. Misticismo y Religiones Mistéricas en la obra de Plutarco (Actas del VII Simposio Espa. ol de Plutarco, Palma de Mallorca, 4-6 de noviembre de 2000), Madrid-Málaga, pp. 5-22.

Bernabé A., 2002A, 'Referencias a textos órficos en Diodoro', [in:] L. Torraca (ed.), Scritti in onore di Italo Gallo, Napoli, pp. 67-96.

Bernabé A., 2002B, 'Un "resumen de historia del orfismo" en Strab. 7 fr. 18', [in:] M. J. Barrios, E. Crespo (eds.), Actas del X Congreso Español de Estudios Clásicos (21-25 de septiembre de 1999), vol. 3, Madrid, pp. 59-66.

Bernabé A., 2007A, 'El silencio entre los órficos', Ilu 19, pp. 53-66.

Bernabé A., 2007B, 'Sur le rite décrit dans les colonnes II et VI du Papyrus de Derveni. Que peut-on faire avec un oiseau?', Les études classiques 75, pp. 157-170.

Bernabé A., 2008, 'La teogonía órfica citada en las Pseudoclementinas', Adamantius 14, pp. 79-99.

Boulanger A., 1937, 'L'orphisme à Rome', Revue des études latines 15, pp. 121-135.

Bousset W., 1913, Kyrios Christos. Geschichte des Christusglaubens von den Anfängen des Christentums bis Irenaeus, Göttingen. 
Brisson L., 1990, 'Orphée et l'Orphisme à l'époque impériale. Témoignages et interprétations philosophiques de Plutarque à Jamblique', [in:] H. Temporini (ed.), Aufstieg und Niedergang der römischen Welt, T. 2, vol. 36, Berlin-New York, pp. 2867-2931.

Brisson L., 1995, Orphée et l'Orphisme dans l'Antiquité gréco-romaine. Collected Studies, Aldershot.

Brisson L., 2008, 'El lugar, el papel y el significado del orfismo en el neoplatonismo', [in:] A. Bernabé, F. Casadesús (eds.), Orfeo y la tradición órfica. Un reencuentro, vol. 2, Madrid, pp. 1491-1517.

Casadesús F., 2008A, 'El Papiro de Derveni', [in:] A. Bernabé, F. Casadesús (eds.), Orfeo y la tradición órfica. Un reencuentro, vol. 2, Madrid, pp. 459-494.

Casadesús F., 2008B, 'Orfismo y estoicismo', [in:] A. Bernabé, F. Casadesús (eds.), Orfeo y la tradición órfica. Un reencuentro, vol. 2, Madrid, pp. 1307-1337.

Casadio G., 1990, 'Aspetti de la tradizione orfica all'alba del cristianesimo', [in:] La tradizione. Forme e modi. Studia Ephemeridis Augustinianum, vol. 1, Roma, pp. 185-204.

Clemen C., 1913, Der Einfluss der Mysterienreligionen auf das älteste Christen, Giessen.

Cumont F., 1929, Les religions orientales dans le paganisme romain, Paris.

Dieterich A., 1913, Nekyia. Beiträge zur Erklärung der neuentdeckten Petrusapokalypse, Leipzig.

Edmonds R. G., 2013, Redefining Ancient Orphism, Cambridge.

Ferwerda R., 1973, 'Le serpent, le noeud d'Hercule et le caducée d'Hermès. Sur un passage orphique chez Athénagore', Numen 20, pp. 104-115.

Frazer J., 1913, The Golden Bough, London.

Hernández R. M., 2006, El orfismo y la magia, Madrid [diss.].

Herrero M., 2007, 'Las Fuentes de Clem. Alex. Protr. II 12-22. Un tratado sobre los misterios y una teogonía órfica', Emerita 75, pp. 19-50.

Herrero M., 2008A, 'Orfismo en Roma', [in:] A. Bernabé, F. Casadesús (eds.), Orfeo y la tradición órfica. Un reencuentro, vol. 2, Madrid, pp. 1383-1411.

Herrero M., 2008B, 'Orfismo y Cristianismo', [in:] A. Bernabé, F. Casadesús (eds.), Orfeo y la tradición órfica. Un reencuentro, vol. 2, Madrid, pp. 1527-1574.

Herrero M., 2010, Orphism and Christianity in Late Antiquity, trans. J. Ottman, D. Rodríguez, Berlin.

Irwin E., 1982, 'The song of Orpheus and the New Song of Christ', [in:] J. Warden (ed.), Orpheus. Metamorphoses of a Myth, Toronto, pp. 51-62.

Jourdan F., 2005, 'Manger Dionysos. L'interpretation du myth du démemberment par Plutarque a-t-elle été lue par les néo-Platoniciens?', Pallas 67, pp. 153-174. 
Jourdan F., 2006, 'Dionysos dans le Protréptique de Clément d'Alexandrie. Initiations dionysiaques et mystères chrétiens', Revue de l'histoire des religions 223, pp. 265-282.

Jourdan F., 2008, 'Le Logos et l'empereur, nouveaux Orphée. Postérité d'une image entrée dans la littérature avec Clément d'Alexandrie', Vigiliae Christianae. A Review of Early Christian Life and Languages 62, pp. 319-333.

Jourdan F., 2010A, Orphée et les chrétiens. La réception du mythe d'Orphée dans la litérature chrétienne grecque des cinque premiers siècles, vol. 1, Paris.

Jourdan F., 2010B, Poème judéo-hellénistique attribué à Orphée. Production juive et réception chrétienne, Paris.

Jourdan F., 2011, Orphée et les chrétiens. La reception du mythe d'Orphée dans la literature chrétienne grecque des cinq premiers siècles, Pourquoi Orphée?, vol. 2, Paris.

Jourdan F., 2015, 'Orpheus and Orphism in the Christian Literature (in Greek) of the First Five Centuries', [in:] W. Brandes, A. Demandt, H. Krasser (eds.), Antike Mythologie in christlichen Kontexten der Spätantike, Berlin-München-Boston, pp. 193-206.

Marcovich M., 1973, 'Orphic fragment 226 Kern (ap. Clem. Strom. VI, 17, 1 Stählin)', Rheinisches Museum für Philologie 116, pp. 359-360.

Nock A. D., 1928, Early Gentile Christianity and its Hellenistic Background, New York.

Pérez L., 2010, 'Los misterios de Orfeo en Protréptico de Clemente de Alejandría', Circe 14, pp. 119-132.

Pérez L., 2011, 'Orfeo y el plagio de la filosofía hebrea. Citas órficas en Stromata 5.14 de Clemente de Alejandría', Circe 15, pp. 113-131.

Reitzenstein R., 1927, Die hellenistischen Mysterienreligionen. Ihre Grundgedanken und Wirkungen, Leipzig - Berlin.

Santamaría M. A., 2008, 'El Orfismo en Luciano y la segunda Sofistica', [in:] A. Bernabé, F. Casadesús (eds.), Orfeo y la tradición órfica. Un reencuentro, vol. 2, Madrid, pp. 1411-1442.

Vicari P., 1982, 'Sparagmos. Orpheus among the Christians', [in:] J. Warden (ed.), Orpheus. Metamorphoses of a Myth, Toronto, pp. 63-83.

West M. L., 1983, The Orphic Poems, Oxford. 